\title{
Reflective study on participatory diagnosis as a community research strategy
}

\author{
Estudo reflexivo sobre o diagnóstico participativo como estratégia de pesquisa em comunidades \\ Estudio reflectivo sobre el diagnóstico participativo como estrategia comunitaria de investigación
}

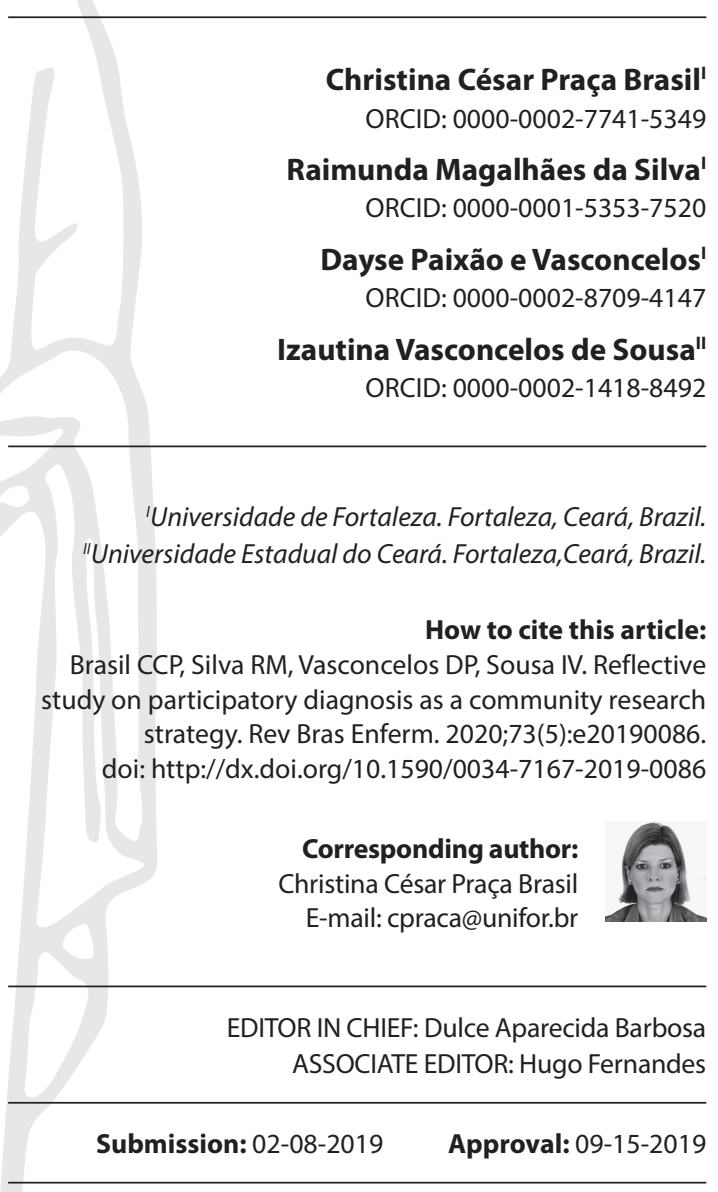

\begin{abstract}
Objectives: to conceive a theoretical-reflective discussion about participatory diagnosis as a methodological option in participatory research. Methods: this is a reflection study, based on an experience that used participatory diagnosis as a research strategy in a socially vulnerable community. It was intended to implicate social groups in the search for identification and solution to the problems. Results: the use of participatory diagnosis has provided significant results regarding the importance given by participants to community empowerment in the fight for health, quality of life and social empowerment. Final Considerations: participatory research and its relationship to participatory diagnosis favors the understanding of social issues, including health conditions, education and effective participation in problem solving. Descriptors: Social Marginalization; Health Promotion; Social Participation; Qualitative Research; Community-Based Participatory Research.
\end{abstract}

\section{RESUMO}

Objetivos: conceber uma discussão teórico-reflexiva acerca do diagnóstico participativo como opção metodológica na pesquisa participativa. Métodos: trata-se de um estudo de reflexão, a partir de uma experiência que utilizou o diagnóstico participativo como estratégia de pesquisa em uma comunidade socialmente vulnerável, com o intuito de implicar grupos sociais na busca de identificação e solução para os problemas. Resultados: a utilização do diagnóstico participativo oportunizou resultados significativos no que se refere à importância dada pelos participantes ao fortalecimento comunitário na luta por saúde, qualidade de vida e empoderamento social. Considerações Finais: a pesquisa participativa e a sua relação com o diagnóstico participativo favorece a compreensão de questões sociais, incluindo as condições de saúde, de educação e de participação efetiva nas soluções de problemas. Descritores: Vulnerabilidade Social; Promoção da Saúde; Participação Social; Pesquisa Qualitativa; Pesquisa Participativa Baseada na Comunidade.

\section{RESUMEN}

Objetivos: concebir una discusión teórico-reflexiva sobre el diagnóstico participativo como una opción metodológica en la investigación participativa. Métodos: este es un estudio de reflexión, basado en una experiencia que utilizó el diagnóstico participativo como estrategia de investigación en una comunidad socialmente vulnerable. Se pretendía implicar a los grupos sociales en la búsqueda de identificación y solución a los problemas. Resultados: el uso del diagnóstico participativo ha proporcionado resultados significativos con respecto a la importancia dada por los participantes al empoderamiento de la comunidad en la lucha por la salud, la calidad de vida y el empoderamiento social. Consideraciones Finales: la investigación participativa y su relación con el diagnóstico participativo favorecen la comprensión de los problemas sociales, incluidas las condiciones de salud, la educación y la participación efectiva en la resolución de problemas.

Descriptores: Vulnerabilidad Social; Promoción de la Salud; Participación Social; Investigación Cualitativa; Investigación Participativa Basada en la Comunidad. 


\section{INTRODUCTION}

Participatory research, from its conception, aims to attach value to the solution of questions concerning the problems of marginalized population groups and the broadening of knowledge of social sciences. This through actions anchored in reality and the participation of research subjects as co-producers of knowledge $^{(1)}$. Along this path, several variants of participatory research emerged, among which action research ${ }^{(2)}$, intervention research and participatory research can be highlighted ${ }^{(3)}$.

Action research was founded by Kurt Lewin in 1978. Lewin believed that researchers, being present in the investigation and being included in the field, modify the object analyzed through their action ${ }^{(2)}$. This type of investigation has changed over the years, due to social influences and authoritarian governments in some countries, resulting in the so-called critical action research. This research departed from the American experience, moving toward emancipatory ideations and self-management. This was strongly present in community and popular education movements ${ }^{(1-2)}$.

Conducting an intervention research aims to investigate the life of collectivities in its qualitative diversity, adopting a socioanalytical intervention. Community experiences association with social and organizational experiences requires scientific rigor establishment to obtain a deeper understanding of the setting and the production of culturally contextualized interventions aligned with everyday life ${ }^{(4)}$. Therefore, it is essential that in a participatory research, knowledge is accessible to everyone and serves as an instrument to assess the quality of life of a social group.

Participatory research, which is evident in this manuscript, is a methodology with general assumptions, involving different modes of investigative actions and prioritization of objectives ${ }^{(4)}$. The forerunners and inspirers in Brazil were Paulo Freire and Carlos Rodrigues Brandão, propagators of this proposal in the popular education projects of the 1960's and 1990's. the creation of an educational network composed of differentiated knowledge, in all involved, there is the same level of importance ${ }^{(1,4)}$.

Considering the objective of participatory research, the various techniques used in their pathways and the focus on intervention to improve the life processes of human groups, there is a strong connection between this investigative strategy and participatory diagnosis (PD). It is worth noting that the PD emerged from Participatory Rural Diagnosis (PRD), created in the 1980s, to allow the population the right to reflect and opine about their own reality, thus enabling collective decision-making ${ }^{(4-5)}$. PD should be understood as a methodology that guarantees social participation in the planning and implementation of public policies ${ }^{(4-5)}$.

Thus, the possibilities brought about by participatory research are many and benefit the understanding of several social issues, including health conditions and considering the point of view of those who, in fact, live and are influenced by health determinants and conditioning factors ${ }^{(6)}$. However, it is important to be clear that, many times, its application becomes a challenge due to the demand for a transformation in researchers' posture. That is, participants and researchers cooperate reciprocally for the construction of a shared knowledge.

This paper turns to participatory diagnosis as a research strategy in communities. This enables the creation of alternatives for the collective construction of thought promoting thoughts, proposing solutions or resolute intentions focused on health issues ${ }^{(6)}$. This manuscript is guided by the following guiding question: what is the role of participatory diagnosis as a strategy intertwined with participatory research to develop the protagonism of the population in the discussion of health conditions?

Nevertheless, this paper aims to conceive a theoretical and reflective discussion about participatory diagnosis as a methodological option in participatory research, aiming to broaden the protagonism of the population in discussions about health conditions.

\section{REFLECTIVE AND METHODOLOGICAL ASPECTS}

The theoretical reflection now developed is based on an experience with participatory diagnosis as a participant research strategy ${ }^{(4)}$. It proposes the involvement of social groups in the search for solutions to their problems, including a process of perception of what is posed and the development of actions to plan reality change.

Participatory research is coined in qualitative episteme ${ }^{(4)}$. It supports the indication of ways to reach a starting point, helping to understand the health-disease processes of individuals and communities. In this type of research, it is necessary to develop a dialogue between theory and method in order to give meaning to 'data' and not neglect the contextualization of hierarchical and situational relations described or pointed out by their interlocutors.

This study was approved by the Ethics Committee of Universidade de Fortaleza, under Opinion 1,146,837. Data collection and reflexive movement were performed from January 2016 to January $2018^{(6-7)}$, based on the information obtained from the PD strategy in health with residents of the community under investigation.

The findings served as an analytical basis for the interpretive and reflective thinking developed in this manuscript. From the perspective of the residents, the problems that interfered with their health conditions were identified. The community in question is located in the city of Fortaleza, Ceará State, Brazil, and is marked by an overview of vulnerability and social inequality.

It is noteworthy that this article included the statements of some of the 31 key informants (KI) who participated in the methodological experiment. They are residents of the community under investigation, whose reports support the argumentative analysis of the reflections presented. To protect the identities of participants, they were coded with the letters "KI" (key informant) followed by numbers 1 to 31 , corresponding to the ordering of the interview.

Participatory methodology and PD as anchors in conducting the fieldwork made possible, from the experience of respondents and researchers, a reflection on participatory research, its contribution to the translation of common sense to academic language, as well as to strengthening community empowerment $t^{(3,6)}$.

Participatory study operationalization with the assumptions of participatory diagnosis allows the use of different means of information collection, which happens in the adoption of different processes of data analysis. This theoretical reflection was constituted in two analytical categories: "participatory diagnosis as a magnifying glass for participatory research", which enables the discussion about the importance of participatory diagnosis 
in the development of qualitative and participatory research; and "participatory research as a promoter of community empowerment".

\section{Participatory diagnosis as a magnifying glass for partici- patory research}

Participatory diagnosis is used to apprehend the main problems of a place/community, and may cover several areas such as social, economic, cultural, environmental, among others ${ }^{(8)}$. Its full scope is only enhanced if researchers use the maximum instrumental possibilities that this strategy allows. In some studies that adopt this participatory approach ${ }^{(1,7,9)}$, different tools were adopted, among which stand out: semi-structured interview, cross-sectional path, participatory mapping and community workshops.

Semi-structured interview plays a role in participatory diagnosis by being guided by key questions, contributing to open dialogue and free declaration about participants' perceptions $s^{(1,7,9)}$. Cross-sectional path helps to conceive and obtain diverse information about the territory, being carried out together with the study participants ${ }^{(7,9)}$. Participatory mapping is considered a reality observation tool, in which participant analyzes everything around him and builds maps about the condition of the place and the people who live in it ${ }^{(5)}$. Community workshops represent systematic contacts with residents of the study site, through which the perspectives generated by these activities define the physical and social spaces that represent the realities reported by research participants ${ }^{(5)}$.

A study by Sousa et al. ${ }^{(7)}$ shows that participatory diagnosis paved the way for the triangulation of data collection strategies that allowed community engagement such as home interviews, street walks and focus groups.

Researchers ${ }^{(6-7)}$ point out that the interview was conducted through open questions. This allowed the analysis of living conditions and knowledge of participants' socioeconomic profile, as well as helping to understand how participants attribute meaning to health, as explained in the following report:

Health is not the absence of disease ... health is a complete physical, social, psychological, mental well-being and you need to be complete. [...] Economic issue...this influences health...social, psychological, mental, spiritual issue [...] this is all health, right? (KI8)

This position represents the awareness that health depends on intersectoral, interdisciplinary and holistic actions, being a knowledge obtained from the lived reality. KI8 positioning does not represent a conception of health imposed or influenced by health professionals or other actors. It is the view of those who believe that improving economic, working or income conditions and psychological factors positively influence people's health.

The report also illustrates participants' perception that health is produced from the socio-historical context and guaranteed by a set of articulated strategies in order to produce improvements in the community's living conditions ${ }^{(10)}$. From this perspective, the concept of health was pointed by the residents considering historical, socioeconomic, religious, social class, among others. Understanding the concept of health from the point of view of others leads to the challenge of giving answers to the questions regarding their being and their reality. This understanding benefits the reconstruction of health concepts and practices as an imperative mission for a good life, based on participation and social control ${ }^{(10)}$.

Participatory diagnosis is characterized as a piece that provides many benefits, including a better understanding of the local reality. It also allows, from the results, the planning of actions aimed at improving health conditions of people and communities involved in the process $s^{(5,9)}$.

Street walk and photographic record carried out in the research by Sousa et al. ${ }^{(7)}$ made it possible to understand the factors that were identified by the residents as problems in the territory and that impacted their health conditions. This is quite clear from the $\mathrm{KI}$ reports, by pointing out in situ the socio-structural weaknesses present in the community:

Water is running, people drain the sewers...people put feces to run through those pipes. Sometimes it clogs everything up. Right now, if you get in there, you see it all clogged up...water running down the path where you pass, where children pass, where everyone passes. In addition, there is a lot of garbage on the streets and no sanitation! (KI29)

KI29's speech expresses the thinking of many residents about the vulnerability and difficult environmental conditions that impact on community health. Throughout the physical space covered, there were problems related to the accumulation of urban solid waste and the lack of sanitation.

Environmental conditions represent one of the most important determinants of health and can positively or negatively influence health promotion and disease prevention. In the approach to disease prevention, the goal is to prevent disease. The individual becomes the target of the intervention, becoming co-responsible for their health status and the reduction of behaviors that expose them to risk factors ${ }^{(10)}$.

Carrying out two focus groups in the community in focus ${ }^{(7)}$ allowed to broaden the discussion about the problems that affect the residents. Participants expressed opinions and feelings related to the conditions in which they live, as well as suggestions about solution strategies. These aspects led us to realize the resolving potentialities that emerge from the integrated force of the population:

We feel abandoned ... as if we didn't exist there, because in people's mouth, people from 'Baixada' [the poorest region of the community] are not good. That's what people say... I'm the head of the party organization [child's day], we are nine..., Then we buy gifts and one person donates candy, another donates lollipop, sometimes when we can, we buy gifts, buy dolls, balls and all that. We've been doing this for about five years, but there are still people talking... $(\mathrm{KI} 2)$

For the focus group to be successful, it needs to be well planned, as it aims to gather information, deepen and interact among participants. The diverse techniques used by participatory diagnosis allow for a stronger involvement of participants with the questions posed for discussion ${ }^{(5,9)}$. In this context, researchers and "researched" are collectively committed to achieving 
the answers, through a relationship that always tends towards horizontality. This condition allows researchers to get closer to reality, as it appears, and for study participants to realize their potentialities and weaknesses.

Moreover, health promotion strategies are related to autonomy and individual and collective empowerment. When they are associated with social participation, they make it possible to transform and improve living and health conditions, as they include daily actions in the micro-political space of the lives of individuals and communities ${ }^{(10)}$.

In the speech of $\mathrm{KI}$, the feeling of social dislocation established by the condition of vulnerability is associated with coping tactics. The discussion showed that, while the community feels marginalized, it also creates vicissitudes to improve relationships between community members, that is, it creates mechanisms to become active and participatory.

It is evident, among other aspects already discussed, the concern of participatory research with the role of researchers within the context. It leads to researcher-researched relationship problematization, in order to establish trust and other favorable conditions for better information capture ${ }^{(4)}$. Such understanding is also perceived in participatory diagnosis. It thus shows that qualitative researchers employing participatory methodologies, such as participatory diagnosis, need to be vigilant to the subjective elements of the empirical field and the relationship created between all participants (researchers and other study subjects) (4-5). It will be essential to relativize the idea of "truth", rejecting the absolute idea of neutrality, objectivity and totalization of knowledge.

\section{Participatory research as a promoter of community empowerment}

It is possible to reflect on the possibilities of increasing community empowerment. Participatory research adopts a conception of science engaged in strengthening subjects, assisting them in their commitment to social demands. This direction is relevant because, often, the involvement of the subjects with the causes that concern their context causes them to follow transdisciplinary paths, seeking to know/recognize the importance of different knowledge. Such thinking allows us to understand the dynamics of reality that intertwines between the most diverse knowledge that incorporate true learning networks in and of life ${ }^{(5,8)}$. In this context, it is believed that, given the setting of any participatory study, it is important to build a path that strengthens the adherence of the subjects to dialogue with the guiding questions of research and the construction of knowledge.

Empowerment consists in instituting possibilities for a person or group of people to understand what affects and weakens them, enabling them to look for ways to cooperate to improve or maintain what is elementary or precious to them. In this context, participatory research promotes opportunities for reflection, which contribute to empowerment. That is what some of the KI proclaim:

It's like I said ... the boys say, "What is our street flooded with? Whose fault is that?" And I reflect that it's our fault, because we put the trash in the middle of the street! (KI)
Sometimes I also think that if the government came in with more lectures and these educational things, arts groups and theater, encouraging people to behave better in health and everything. I think it would help a lot because the lack of knowledge is big and it hurts many people's lives! (KI)

The aforementioned statements show that the community has the idea that to promote health it is necessary to have changes in lifestyle and behavior. It is noteworthy that the information is important and necessary, but not enough. It is necessary to investigate and act on the possibilities and interests of the subjects and collectivities in carrying out what is informed or prescribed, whether by health services and professionals, whether by lay or specialized media. It is common to blame those who do not adopt the recommendations, disregarding that the causes are intertwined with social, economic and cultural dimensions that are outside individual governance ${ }^{(10)}$. In this sense, participant research makes it possible to balance this judgment, creating different ways to reflect on the health conditions of a place or a community.

Research conducted by Sousa et al. ${ }^{(7)}$ illustrates a methodological procedure in which participatory diagnosis is used as an investigative strategy. Those involved were people representative of a situation to be transformed or improved, who can produce knowledge about the actions developed. Processes of this nature lead participants to identify concrete community problems, discuss them, and seek solutions.

It is worth highlighting, in this setting, that health promotion cannot be understood only as a set of procedures aimed at reducing risks of illness. It must be understood as a socially constructed and understood practice, under the belief that the success of the desired changes depends on community participation and protagonism. Subjects should no longer be seen as 'target population' and should be recognized as active subjects ${ }^{(10)}$.

Therefore, this article is based on the reflection that presents the construction of knowledge through sharing ${ }^{(2)}$. At least for some time, it is necessary for researchers to change places and to look for learning to arise not by thinking the other through a personal vision, but by trying to reposition itself in the place of the other, that is, the community ${ }^{(2)}$. In the field of participatory research, researchers must present themselves as representatives of a science that is concerned with popular causes. Therefore, they contribute to the organization of spaces for collective participation and community empowerment.

Nevertheless, opening spaces for discussion on topics involving politics, popular education, health and community organization constitute possible relationships to transform reality ${ }^{(1)}$. Participating research experiences move towards the articulation between theory/practice and subject/object. This occurs insofar as knowledge and action on reality will be carried out in the investigation of local needs and interests in the production of organizational forms and effective action on this reality. This can lead to social and political transformations, giving excluded populations an active presence in history ${ }^{(3)}$.

Through experience with the investigated community, it is possible to ratify the idea that social issues should be debated with people who experience them. It is essential to consider 
the local context, the subjectivities and the complexity that surrounds the processes of social transformation. These elements are characteristic of the basic framework of participatory research and are manifest as basic data for the construction and exercise of active citizenship ${ }^{(1,3)}$.

\section{FINAL CONSIDERATIONS}

Participatory diagnosis application provided a participatory context that went beyond initial expectations. Participants related the importance of participation in the study to community empowerment in terms of the struggle for health and the pursuit of quality of life.

The possibility of triangulating the data collection methods used in participatory research and participatory diagnosis helps to bring researchers closer to reality. This facilitates understanding on subjects, weaknesses and potentialities of the community under investigation. It is reaffirmed that participatory methodologies enable effective interaction of researchers with community and among its members, through the creation of spaces for speech, listening and decision-making. This interaction also favors a closer understanding of the real - one of the great intentions of qualitative health research.
It is noted that from the experience and reflection process established in this study, it was learned that participatory research corroborates the science that engages in dialogue with the movement of life. Therefore, debates about health and other themes are promoted, based on people's own understanding.

It can be guaranteed that the transformation of the lived reality would not happen only from what was perceived by researchers, because transformation occurs through combination of knowledge that governs the horizontality of social relations. Moreover, the look on the reality that surrounds research's social actors (researchers and participants) happens at the moment of participatory experience in the study place and group interaction. Interaction between academic knowledge and popular knowledge is a crucial point for understanding what is put in the 'researched' place.

\section{FUNDING/ACKNOWLEDGMENT}

This study received financial support from Fundação Edson Queiroz/Universidade de Fortaleza - Notice 30/2017. We appreciate the valuable contributions of researchers José Eurico de Vasconcelos Filho, Olivia Paulino Pinto and Timothy Joseph Finan for the development of this study.

\section{REFERENCES}

1. Streck DR. Participatory research methodologies and popular education: reflections on quality criteria. Interface. 2016;20(58):537-47. doi: 10.1590/1807-57622015.0443

2. Melo ASE, Maia Filho ON, Chaves HV. Lewin and action research: genesis, application and purpose. Fractal Rev Psicol. 2016;28(1):153-9. doi: $10.1590 / 1984-0292 / 1162$

3. Hickey SD, Maidment SJ, Heinemann KM, Roe YL, Kildea SV. Participatory action research opens doors: Mentoring Indigenous researchers to improve midwifery in urban Australia. Women Birth. 2018;31(4):263-8. doi: 10.1016/j.wombi.2017.10.011

4. Grieb SD, Eder MM, Smith KC, Calhoun K, Tandon D. Qualitative Research and Community-Based Participatory Research: Considerations for Effective Dissemination in the Peer-Reviewed Literature. Prog Community Health Partnersh. 2015;9(2):275-82. doi: 10.1353/cpr.2015.0041.

5. Nelson DR, Finan TJ. Diagnóstico participativo do bairro Canindezinho: a perspectiva dos moradores. Fortaleza: Provoz; 2015.

6. Sousa IV, Brasil CCP, Silva RM, Vasconcelos DP, Vasconcelos Filho JE, Pinto OP, et al. Pesquisa participativa no protagonismo comunitário para abordar questões de saúde: um olhar sobre o diagnóstico participativo. Atas do $7^{\circ}$ Congresso Ibero-Americano em Investigação Qualitativa Atas CIAIQ2018, 2018 Jul 13-18; Fortaleza. Fortaleza: CIAIQ; 2018. v. 2. p. 1068-1077.

7. Sousa IV, Brasil CCP, Silva RM, Vasconcelos DP, Silva KA, Bezerra IN, et al. Diagnóstico participativo para identificação de problemas de saúde em comunidade em situação de vulnerabilidade social. Ciênc Saúde Colet. 2017;22(12):3945-54. doi: 10.1590/1413-812320172212.25012017

8. Castro MG, Abramovay M. Guia do diagnóstico participativo. Brasília: Flacso; 2015.

9. Tomasi YT, Souza JB, Madureira VSF. Community diagnosis in the family health strategy: potential and challenges. Rev Enferm UFPE [Internet]. 2018 [cited 2019 Jan 02];12(6):1546-53. Available from: https://periodicos.ufpe.br/revistas/revistaenfermagem/article/ viewFile/230505/29180

10. Carvalho FFB, Cohen SC, Akerman M. Reflecting on the established in Health Promotion to problematize 'dogmas'. Saúde Debate [Internet]. 2017 [cited 2019 Jan 03];41(3):265-76. Available from: https://www.scielo.br/pdf/sdeb/v41nspe3/0103-1104-sdeb-41-spe3-0265.pdf 